\title{
Steve Lau and John De Lucy (eds.) (2017). Chinese Labour Corps: Photographs from
}

the WJ Hawkings Collection. Myosotis Books. 96 pp., ISBN-10: 1999806603.

This new work, published in English, French and Mandarin, draws upon recentlydiscovered photographic evidence to cast a fresh light upon the work and role of the Chinese Labour Corps (CLC) on the Western Front during the First World War. At its core lie the photographs taken by William James Hawkings in China and France between 1917 and 1919 and rediscovered by his grandson, John De Lucy, in 2014. These images formed the core of $A$ Good Reputation Endures Forever-the first UK exhibition to focus exclusively on the volunteers of the CLC-and now, thanks to the efforts of John De Lucy and Steve Lau, highlights from the collection are available to a wider audience.

William James Hawkings was born in Somerset in 1883, and moved to China in 1908 to work for the British American Tobacco Company. A fluent Chinese speaker, he travelled to the CLC recruitment centre in Weihaiwei in early 1917, and was appointed Superintendent of Number 4 Party CLC. He arrived in France in August 1917, and was posted to Calais with No. 12 Company CLC to work in the busy docks. In late 1917 W.J. Hawkings travelled to China to collect more recruits, returning to France seven months later. He subsequently served with No. 103 Skilled Trades Company at Noyelles-sur-Mer, prior to taking over command of the No. 30 Unskilled Labour Corps at Bourbourg. He was demobilised in August 1919 and returned to China in early 1920. Throughout his time with the CLC, Hawkings used his camera to record the lives of the men under his command. His ability fully to engage with his subjects-and their obvious ease with their chronicler-allowed him to capture a series of images of military life that are remarkable for their informality and humanity.

The photographs have been arranged to cast a light on various core aspects of the experiences of the 96,000 Chinese volunteers who served under British command during the Great War. They thus reflect the lives of an extraordinary group of Chinese working men during a period of tumultuous change. At the outbreak of the First World War, China was in the process of transforming from Empire to Republic. The Chinese government was keen to develop its place on the world stage, and saw support for the Allies as a route to both recovering German possessions in Shandong Province and countering the increasing influence of Japan in the region. By mid-1916 Britain was suffering from an acute shortage of labour, as the nation struggled to deal with the losses incurred on the Western Front. Many jobs at home were taken over by women, but the British government was eager to find a means of releasing the numerous troops employed on vital labour duties behind the front lines to serve in the trenches.

The recruitment of Chinese workers offered a solution to this problem. It also offered the Chinese government an opportunity to align itself with the Allied cause. From early 1917, large numbers of Chinese labourers were hired in the north of the country to serve with the British army. Recruitment centred on Weihaiwei in 
Shandong Province. The region's poverty and the relatively high wages offered by British recruiters ensured that there was no shortage of volunteers.

It is within this contextual landscape that the images captured by Hawkings are firmly located. The bulk of the book's narrative takes the form of quotes from contemporary letters, newspaper reports, diaries and other written sources, whilst all of the photographic captions reproduce Hawkings's own descriptions. Thus armed, the reader is taken on an astonishing visual journey from Weihaiwei to the CLC's main camp at Noyelles-sur-Mer in Northern France.

The arrangement of the book is essentially thematic, commencing with an outline of Hawkings's life and then moving on to explore the experiences of the men who served under his command in a range of settings: recruitment and transport, military life, working life, off-duty life, and finally sickness and death. Photographs taken at the point of embarkation reflect the mixed emotions of smartly-uniformed young men setting off on an epic journey to the battlefields of France and Flanders. In marked contrast, many of the images of CLC members at work capture the illconcealed anxiety on the faces of men engaged in the perilous processing of unexploded munitions.

It is, however, the photographs of CLC volunteers at leisure that are perhaps the most astonishing. Here, within the mundane surroundings of camp life, Hawkings has captured something special. Unlike so many official images of the war, his photographs appear to be populated by real people with whom the viewer can immediately connect. The excitement of receiving mail from home is evident in one group shot, just as the pride of a horticulturalist shines through in a photograph of a labourer tending the perfectly laid-out hospital garden at Noyelles-sur-Mer. Elsewhere, a portrait of a man with his pet songbird conveys a special sense of intimacy; and the supreme confidence of a naked young man posing shamelessly for the camera whilst waiting to shower serves as a reminder of the universal and timeless optimism of youth.

But such optimism was often misplaced, and Hawkings did not hesitate to chronicle the sacrifices of the CLC workers. Although members of the Chinese Labour Corps did not serve on the front line, some 3,000 lost their lives whilst serving in France and Flanders. Their role in maintaining Britain's military infrastructure made them prime targets for German artillery and aircraft, whilst their dangerous work with munitions and explosives also led to many casualties. Others died in industrial accidents, but the biggest killer was disease, particularly the deadly influenza epidemic of 1918-19.

Given this context, it is unsurprising that many of the images reproduced reflect upon sickness and death. The work undertaken by the British medical staff based a Noyelles-sur-Mer is chronicled, with particular emphasis being given to the strict regime of inspection and treatment undertaken to minimise the risk of the spread of trachoma and conjunctivitis amongst the closely-packed CLC workers based there. Moreover, in these images we also find reminders that not all of the Chinese volunteers based there were drawn from the labouring classes. Here we also see the 
faces of young members of China's intellectual elite-many linked to the YMCAwho had travelled to France to evangelise and to educate their fellow countrymen.

But if these photographs are enlightening, it is a group of images recording the funeral of a CLC member that engenders the greatest emotional impact. As we look upon the funeral party escorting their dead companion's Union Jack-draped coffin to his final resting place, we witness both British and Chinese warriors walking-albeit momentarily-in step.

The story of Chinese labour during the Great War has long been ignored by scholars and historians. Some recent works have gone some way towards casting a fresh light upon this shamefully neglected story, but it is through works such as this that we are perhaps best able to breathe fresh life into the stories of those who travelled so far to serve in a foreign war. The time has come to remember the "forgotten of the forgotten".

Craig Barclay and Rachel Barclay

Durham University 